\title{
WARTOŚĆ CELIBATU W NAUCE ŚWIĘTEGO PAWŁA
}

Rok świętego Pawła, ogłoszony przez Benedykta XVI w dniu 28 czerwca 2008 roku, staje się szczególną inspiracją, aby kolejny raz wsłuchać się w głos zwiastuna Jezusa Chrystusa, który jak sam mówi: „został ustanowiony [...] nauczycielem pogan $\mathrm{w}$ wierze i prawdzie"1. Kierując się zatem zachętą Ojca Świętego Benedykta XVI, aby w Roku Apostoła Narodów „słuchać i uczyć się od niego - naszego nauczyciela - «wiary i prawdy», z których wywodzą się motywy jedności uczniów Chrystusa"2, wsłuchujemy się w przekaz biblijny, aby dostrzec wartość celibatu w nauczaniu św. Pawła.

Słowa Jezusa dotyczące małżeństwa i bezżennego stanu życia zostały zachowane w przekazie ewangelicznym ${ }^{3}$, ale niestety, przekazy te nie mówią nam nic na temat życiowej realizacji tej rady ewangelicznej w czasach Jezusa. Pewną konkretną sytuację opisuje nam św. Paweł w jednym ze swoich Listów do gminy chrześcijańskiej w Koryncie. Ukazuje on ewolucję w rozumieniu małżeństwa i celibatu w kościele lokalnym, jak również orientację samego Apostoła w tej

${ }^{*}$ Ks. Andrzej Nowicki - doktor nauk prawnych w zakresie prawa kanonicznego, kanclerz Kurii Diecezjalnej Toruńskiej.

${ }^{1} 1 \mathrm{Tm} \mathrm{2,} \mathrm{7;} \mathrm{por.} 2 \mathrm{Tm} \mathrm{1,} 11$.

${ }^{2}$ Benedykt XVI, Stuchajmy św. Pawła i uczmy się od niego, Homilia Benedykta XVI wygłoszona podczas Nieszporów w bazylice św. Pawła za Murami w dniu 28 czerwca 2008 r., "L'Osservatore Romano", (wyd. polskie), nr 7-8 (305)/2008, s. 26.

${ }^{3}$ Por. Mt 19, 10-12. 
materii. Chociaż nauka Pawła zawarta w Pierwszym Liście do Koryntian nie stanowi systematycznego wykładu tej problematyki, to jednak nie można mieć tego za złe Apostołowi, ponieważ odpowiada on na konkretne pytania nowej wspólnoty chrześcijańskiej. Pomimo wielu problemów powstałych w gminie jego nauka jest jasna i stanowi pewną całość.

Korynt był szczególnym miastem, dobrze znanym Pawłowi ${ }^{4}$. Jego mieszkańcy, nawróceni z pogaństwa, w zakresie małżeństwa i życia seksualnego zastosowali dość krańcowe zasady ${ }^{5}$. Według tekstu, żyli w tej wspólnocie ludzie będący w małżeństwie ${ }^{6}$ albo w separacji ${ }^{7}$ oraz różne kategorie celibatariuszy: ci, którzy nie zawarli małżeństwa ${ }^{8}$; ci, którzy żyli wcześniej w małżeństwie, ale owdowieli"; ci, którzy prawnie opuścili małżonka z motywów wiary ${ }^{10}$; a także narzeczeni, którzy cieleśnie nie współżyli ze sobą ${ }^{11}$.

Już w pierwszym wierszu tego rozdziału znajdujemy ogólne wyrażenie, w którym Paweł mówi, że lepiej żyć w celibacie, niż łączyć się z kobietą. To stwierdzenie Apostoła Narodów dotyczy zarówno pożycia cielesnego w małżeństwie, jak i stosunków poza nim. Paweł kieruje swoje wskazania do wszystkich grup $^{12}$. Reaguje on przeciwko rygoryzmowi Koryntian i apeluje o ludzki realizm. Jednak Apostoł nie sugeruje, że każdy związek mężczyzny i kobiety jest zły. Nie chodzi mu o porównanie „dobrego" ze „złym”, ale „dobrego" z „lepszym”. Słowa św. Pawła nie pomniejszają rangi małżeństwa, co można stwierdzić z jego dalszych wypowiedzi ${ }^{13}$. Apostoł zna dobrze naturę człowieka, dlatego nie każdemu poleca obierać tę formę życia, jaką jest celibat. Jedynie zachęca do pewnych form wstrzemięźliwości w małżeństwie, ale przy obopólnej zgodzie małżonków i zachowaniu umiaru. Nakazuje natomiast wypełnianie obowiązków, które płyną z tego związku. Św. Paweł trzeźwo patrzy na rzeczywistość, dlatego uważa, że dłuższe powstrzymywanie się od współżycia małżeńskiego jednej ze stron może prowadzić do nierządu wskutek słabości ciała ${ }^{14}$.

${ }^{4}$ Por. S. Gądecki, Archeologia biblijna, t. 1, Gniezno 1994, s. 453-455.

${ }^{5}$ Zob. 1 Kor 6, 9-11.

${ }^{6}$ Por. 1 Kor 7, 2-6.

${ }^{7}$ Por. 1 Kor 7,11 .

${ }^{8}$ Por. 1 Kor 7, 25 nn.

${ }^{9}$ Por. 1 Kor 7, 8. 39-40.

${ }^{10}$ Por. 1 Kor 7, 15.

${ }^{11}$ Por. 1 Kor 7, 36-38.

${ }^{12}$ Zob. 1 Kor 7, 25-40.

${ }^{13}$ Por. E. Dąbrowski, Listy do Koryntian. Wstęp - przektad z oryginatu. Komentarz, Poznań 1965, s. 193.

${ }^{14}$ Por. H. Langkammer, Wprowadzenie do ksiag Nowego Testamentu, Wrocław 1982, s. 128; zob. także R. Schnackenburg, Nauka moralna Nowego Testamentu, Warszawa 1983, s. 187. 
Zwracając się do nieżonatych ${ }^{15}$, wśród których znajduje się on sam $^{16}$, ukazuje wartość stanu bezżennego ${ }^{17}$. Taka decyzja, z określonych motywów nadprzyrodzonych, jest darem Boga - charyzmatem ${ }^{18}$ i Paweł ją akceptuje jako dobrą. W każdej sytuacji jego generalna zasada brzmi: „Niech każdy postępuje tak, jak mu Pan wyznaczył, zgodnie z tym, do czego Bóg go powołał"19.

Zasada ta przedstawia prośbę Apostoła, aby trwać w tym stanie, w jakim przyjęło się wiarę. Według św. Pawła, celibat nigdy nie stanowi obowiązku i ma sens tylko wówczas, gdy podejmuje się go w wolności i dla wolności ${ }^{20}$, jako dar. Dar ten pozwala człowiekowi pozostawać bardziej wolnym w służbie Chrystusowi i nie należy go traktować jako „stanu doskonalszego i duchowo korzystniejszego od małżeństwa"21.

Małżeństwo odpowiada woli Bożej w odniesieniu do tych, którzy nie są wezwani do celibatu i, gdy stanowi środek przeciwko nieumiarkowaniu (rozwiązłości), jest jedyną formą jedności mężczyzny i kobiety w ich relacji do Chrystusa. Dlatego małżeństwo jest rzeczywistością pozytywną, a nie negatywną 22 .

Refleksja Pawła odnosi się nie tylko do ministrów danej wspólnoty, ale do wszystkich członków gminy w Koryncie. Gdy odwołuje się do własnego przypadku ${ }^{23}$, to nie uzasadnia swego celibatu własną misja, ale "charyzmatem”, jaki otrzymuje, i który chciałby widzieć u wielu innych osób.

Wśród egzegetów i teologów istnieją kontrowersje dotyczące stanu Apostoła Narodów. Na podstawie tekstów biblijnych nie można ustalić, czy był on wdowcem, czy nieżonatym, czy „zostawił żonę z miłości do Królestwa Bożego"24. Ph. Ménoud utrzymuje tezę, że wziął separację z żoną, gdy się nawrócił ${ }^{25}$. Jednoznaczne są jednak jego osobiste sympatie, które były zwrócone ku życiu w celibacie.

${ }^{15}$ Zob. 1 Kor 7, 25-38.

${ }^{16}$ Zob. 1 Kor 7, 7-8.

${ }_{17}$ Por. 1 Kor 7, 26.

${ }^{18}$ Por. 1 Kor $7,7$.

191 Kor 7, 17.

${ }^{20}$ Por. P. Bony, Ministero, matrimonio e celibato, w: Il ministero e $i$ ministeri secondo il Nuovo Testamento, Milano 1977, s. 736.

${ }^{21} \mathrm{Ph}$. Ménoud, Mariage et célibat selon saint Paul, Revue de théologie et de philosophie 1 (1951), s. 22.

${ }^{22}$ Por. W. Michaelis, Ehe und Charisma bei Paulus, Zeitschrift für systematische Theologie, Gütersloh 1927, s. 426-456.

${ }^{23}$ Zob. 1 Kor 7, 7.

${ }^{24}$ J. Jeremiâs, War Paulus Witwer?, Zeitschrift für die neutestamentliche Wissenschaft und die Kunde der älteren Kirche, Berlin 25 (1926), s. 310 nn.

${ }^{25}$ Por. Ph. Ménoud, dz. cyt., s. 21-34. 
Bezżenność jest, według św. Pawła, szczególnym darem Bożym, bo jak sam mówi: „Każdy otrzymuje własny dar od Boga; jeden taki, a drugi taki”26. Apostoł naucza, że charyzmatem jest każde powołanie. Dlatego małżeństwo czy bezżeństwo nie jest tylko sprawą wyboru jakiejś formy życia przez danego człowieka, ale jest to sprawa daru, który Bóg daje każdemu człowiekowi indywidualnie. Do człowieka należy rozpoznanie i odczytanie tego daru, oraz odpowiedź na Boże wezwanie, które jest powołaniem i charyzmatem²7.

Powołanie każdego chrześcijanina ma swoje ostateczne źródło w charyzmatach, których udziela Duch Święty ${ }^{28}$. Paweł traktuje małżeństwo i celibat jako dwa stany w pełni prawne dla wiernych i dlatego każdy z tych stanów pozwala realizować powołanie powszechne do zbawienia, czyli życie w Chrystusie. Apostoł nigdy nie mówi o celibacie ex professo, ale zawsze w szerszym kontekście, w relacji powołania do świętości. Nigdy nie widzi on w celibacie środka do osiągnięcia najwyższej świętości, podobnie jak w małżeństwie nie widzi przeszkody do osiągnięcia celu wyznaczonego chrześcijaninowi. Celibat jest $\mathrm{w}$ jego oczach charyzmatem, a nie powszechnym powołaniem. Powszechne powołanie, to znaczy życie w Chrystusie, jest drogą do uświęcania siebie i wspólnoty, w której żyje. Dla tych, którzy nie otrzymali charyzmatu, „lepiej jest żyć w małżeństwie, niż płonąć"29, ponieważ małżeństwo jest kompatybilne z życiem w celibacie. Jeśli Paweł preferuje celibat to nie z racji teologicznych, ale praktycznych ${ }^{30}$.

Spotyka się często zarzut, że charyzmatyczne powołanie do bezżenności i powołanie do urzędu kapłańskiego, to dwie różne sprawy. Sugeruje się pozostawienie wolnej decyzji w tej materii temu, który obiera urząd kapłański.

Wydaje się, że sprawa charyzmatu i wolności jest źle rozumiana. Stawiający powyższy zarzut rozumieją charyzmat jako zdolność do bezżeństwa udzieloną od urodzenia. Nie jest to rozumienie poprawne i nie ma nic wspólnego z Pawłowym rozumieniem charyzmatu. Człowiek może się otworzyć lub zamknąć na dary Ducha Świętego, dlatego św. Paweł zachęca: „Starajcie się o większe dary"31, czyli dajcie w swoim życiu wewnętrznym i zewnętrznym więcej miejsca na działanie Ducha Świętego. W rozumieniu św. Pawła charyzmat jest związany z daną funkcją i Duch Święty zawsze udziela swojej łaski temu, kto podejmuje tę funkcję. Dlatego również Kościół łączy urząd kapłański z obowiązkiem celibatu, ponieważ jest przekonany, że do takiej formy życia

${ }^{26}$ Zob. 1 Kor 7, 7.

${ }_{27}$ Por. B. Kuras, Święty Paweł o chrześcijańskiej czystości, Katowice 1987, s. 79.

${ }^{28}$ Por. A. George, P. Grelot, Charyzmaty, w: Stownik teologii biblijnej, red. X. Leon-Dufour, Poznań 1990, s. 114.

${ }^{29} 1$ Kor 7,9

${ }^{30}$ Por. Ph. Ménoud, dz. cyt., s. 24.

311 Kor $12,31$. 
kandydatowi do kapłaństwa hierarchicznego został udzielony charyzmat przez Ducha Świętego. Charakter łaski nie został zniesiony uregulowaniami prawnymi, lecz one stworzyły warunki zewnętrzne, które pozwalają na całkowite oddanie się sprawie Królestwa Bożego ${ }^{32}$.

Apostoł Narodów, sam będąc bezżennym, zachęca tych, „którzy nie wstąpili w związki małżeńskie, oraz tych, którzy już owdowieli"33, aby żyli tak jak on - w celibacie. Jest to rzecz dobra i wzniosła ${ }^{34}$. Jednak ostrzega tych, którzy „nie potrafiliby zapanować nad sobą"35, aby nie podejmowali tej formy życia, jaką jest bezżeństwo. Niech lepiej wstąpią w związek małżeński, niż mają być wystawieni na pastwę grzechu. Bo jak mówi Orygenes: ,jak czyste bezżeństwo jest łaską, tak samo małżeństwo zawarte według Słowa Bożego jest łaską" 36 .

Święty Paweł w Pierwszym Liście do Koryntian, po zakończeniu nauki o nierozerwalności małżeńskiej, powtórnie powraca do problemu bezżeństwa, aby go pogłębić i wyjaśnić motywy, dla których uważa, że dziewictwo jest wyżej postawione $\mathrm{w}$ hierarchii niż małżeństwo. Na początku zaznacza, że jego wypowiedź nie ma charakteru nakazu Chrystusa, ale jest tylko radą człowieka, który doznał miłosierdzia Bożego i któremu można ufać37. Argumentem podawanym przez Apostoła na rzecz dziewictwa są utrapienia ziemskie, a szczególnie cierpienia związane z powtórnym przyjściem Chrystusa ${ }^{38}$.

Święty Paweł apeluje do zdrowego rozsądku chrześcijan, aby wybrali taki stan życia, który nie będzie źródłem nowych ucisków. Wiadomo przecież, że zawarcie małżeństwa nie sprzeciwia się woli Bożej, ale jest związane z przyjęciem wymagających obowiązków małżeńskich i rodzicielskich, które pociągają za sobą kłopoty i udręki. Apostoł chce zaoszczędzić tego wiernym³ ${ }^{39}$. Udręki i kłopoty mają swoje źródło nie w życiu małżeńskim, lecz wywodzą się z faktu nadejścia czasów ostatecznych.

32 Por. G. Greshake, Być kaptanem, Wrocław 1983, s. 158.

${ }_{33} 1$ Kor $7,8$.

${ }^{34}$ Por. M. Wolniewicz, Nauka o bezżeństwie i dziewictwie w Pierwszym Liście św. Pawła do Koryntian, Ruch Biblijny i Liturgiczny 11 (1958), nr 3, s. 194.

${ }^{35} 1$ Kor 7, 9

${ }^{36}$ Origenes, In Matthaeum commentarii 14, 16, w: M. J. Rouët de Journel, Enchiridion Patristicum, Herder 1965, nr 505 (PG 13, 1229): „Deus quidem is est, qui duo in unum compegit, ut, ex quo mulier viro nupsit, duo amplius non sint; et quoniam coniunxit Deus, propterea iis inest gratia, qui a Deo coniuncti sunt; quod non ignorans Paulus conubium Verbo Dei consentaneum gratiam esse pronuntiat, queadmodum castus caelibatus gratia est".

${ }^{37}$ Por. 1 Kor $7,25$.

${ }^{38}$ Por. 1 Kor 7, 26-28.

${ }^{39}$ Por. E. Szymanek, Wykład Pisma Świętego Nowego Testamentu, Poznań 1990, s. 307; A. Jankowski, K. Romaniuk, L. Stachowiak, Komentarz praktyczny do Nowego Testamentu, Poznań-Warszawa 1975, s. 731. 
Ponieważ motywy, dla których jest podejmowana bezżenność, mają wymiar eschatologiczny, to nie można posądzić Apostoła o wygodnictwo i ucieczkę od trudności życia małżeńskiego. Zachęcając do dziewictwa, Apostoł kierował się racjami nadprzyrodzonymi. $Z$ tego powodu w jego nauce wszelkie ziemskie sprawy otrzymują charakter względny i tymczasowy. Z paruzją Chrystusa łączą się prześladowania i różnego rodzaju utrapienia, dlatego w tym wymiarze wartość nieprzemijającą posiada celibat ${ }^{40}$.

Następny argument za celibatem jest zawarty w następującej wypowiedzi: „Mówię, bracia, czas jest krótki” ${ }^{41}$. W świetle całej perykopy widać, że Apostoł stawia wyżej stan bezżenny dlatego, że pozwala on człowiekowi bardziej wykorzystać czas przeznaczony na bieg życia niż małżeństwo. Życie ludzkie jest zbyt krótkie - jakkolwiek byłoby długie - aby można było je zmarnować na sprawy nieistotne. Trzeba wykorzystać je racjonalnie, aby przygotować się na spotkanie z Panem, aby Mu się przypodobać ${ }^{42}$. Chrześcijanin powinien tak żyć, aby jego zaangażowanie duchowe nie było skierowane tylko na życie ziemskie, gdyż nie posiada ono wartości absolutnej, ale ma być skierowane na Boga.

Czasy mesjańskie zostały już zainaugurowane przez Wcielenie i Zmartwychwstanie Jezusa Chrystusa. Chrześcijanie uczestniczą w życiu Zmartwychwstałego, dlatego sprawy ziemskie powinni pozostawić na dalszym planie, bo jak mówi św. Paweł: „przemija postać tego świata” ${ }^{43}$. W ten sposób Apostoł jeszcze raz podkreśla, że żyjąc i korzystając z tego świata, trzeba mieć na uwadze powtórne przyjście Chrystusa i nie można być mocno przywiązanym do dóbr i struktur ziemskich ${ }^{44}$. Należy mieć na uwadze krótkotrwałość i przemijanie obecnego życia, przygotowując się ustawicznie do życia w przyszłym Królestwie Bożym.

Apostoł podkreśla, że żyjemy w czasach ostatecznych. Nie chodzi tu o datę paruzji. "Czasy ostateczne” rozumie on szerzej. Są one nierozłącznym elementem historii zbawienia i zostały przewidziane przez odwieczną Myśl Bożą. Przepajają one świat, a ich unaocznienie dokonuje się poprzez różne znaki, od chwili proklamacji Królestwa Bożego na ziemi, której dokonał Jezus Chrystus. Znaki te, jak podkreśliliśmy już wcześniej, nie pozwalają wyznaczyć daty powtórnego przyjścia Chrystusa na świat, ale są zachętą i sygnałem do nieustannej czujności. Dlatego stan bezżenny, w ujęciu Apostoła Narodów, jest

${ }^{40}$ Por. B. Kuras, dz. cyt., s. 83-84; K. Romaniuk, Studia nie tylko nad św. Pawłem, Poznań 1999, s. 109; M. Wolniewicz, dz. cyt. s. 196-197.

${ }^{41} 1$ Kor 7, 29.

${ }^{42}$ Por. K. Romaniuk, dz. cyt., s. 109; E. Dąbrowski, dz. cyt., s. 202.

${ }^{43} 1$ Kor 7, 31.

${ }^{44}$ Por. E. Szymanek, dz. cyt., s. 307; A. Jankowski, K. Romaniuk, L. Stachowiak, dz. cyt., s. 731-732; R. Rubinkiewicz, Matżeństwo i dziewictwo w nauce św. Pawta (1 Kor 7, 1-40), Zeszyty Naukowe Katolickiego Uniwersytetu Lubelskiego 23 (1980), nr 3, s. 49. 
najodpowiedniejszym wyrazem oczekiwania na powtórne przyjście Chrystusa. Celibat jest znakiem eschatologicznym i posiada wartość nieprzemijająca, gdyż życie w takiej formie rozpoczęte na ziemi, będzie kontynuowane w wieczności. Małżeństwo natomiast jest elementem świata ziemskiego, przemijającego i skończy się, gdy nastanie nowa rzeczywistość zmartwychwstałych. Celibat, będąc znakiem eschatologicznym, uzmysławia człowiekowi, że celibatariusze nie są tak mocno związani z tym światem. Dziewictwo jest również wyrazem eschatologicznego oczekiwania w Kościele ${ }^{45}$. Etyka paruzyjna ${ }^{46}$, prezentowana przez św. Pawła, jest wypadkową treści napomnień moralnych i sposobu ich uzasadniania ${ }^{47}$.

Po przytoczeniu argumentów eschatologicznych za celibatem św. Paweł podaje argument psychologiczno-moralny. Wydaje się, że jest to argument najistotniejszy: dziewictwo jest doskonalsze niż małżeństwo, ponieważ pozwala człowiekowi oddać się bez reszty Bogu ${ }^{48}$. Człowiek bezżenny może oddać Panu całe swoje ludzkie serce, bez konieczności dzielenia go między Boga a rodzinę. Przeciwieństwem tego jest małżeństwo, w którym chrześcijanin przeżywa wewnętrzne rozdarcie, ponieważ nie może całkowicie poświęcić się ani Bogu, ani współmałżonkowi. Z tego rozdarcia bierze swój początek rozterka. Człowiek zadaje sobie pytanie: co wybrać? - czy to co ludzkie?, czy to co Boskie? Bezżeństwo pozwala uniknąć tych rozterek i związanych z nimi pytań. Celibat nabiera takiego znaczenia w ustach św. Pawła dlatego, ponieważ pozwala bez przeszkód trwać przy Panu ${ }^{49}$.

W myśleniu Pawła, celibat jest lepszy w relacji do spraw Bożych niż małżeństwo, ale tylko dla tych, którzy otrzymali go jako powołanie od Pana, jako dar. Dla innych zaś jest właściwsze małżeństwo. Nie wszyscy otrzymują charyzmat życia w celibacie. Jest to praktyczny, a nie teologiczny plan Pawła. Bezżeństwo, które jest nadprzyrodzonym stylem życia, osiąga swoją pełnię, gdy jest na wskroś przeniknięte miłością do Boga i do bliźnich. Miłość ta nie może być ograniczona niczym, a małżeństwo przez swoje obowiązki ogranicza ją. Małżeństwo i dziewictwo na poziomie naturalnym jest oceniane przez św. Pawła jednakowo. Natomiast w porządku nadprzyrodzonym bezżeństwo stawiane jest wyżej, ponieważ pełne oddanie i miłość do Boga można łatwiej osiągnąć w stanie bezżennym.

${ }^{45}$ Por. B. Kuras, dz. cyt., s. 88.

${ }^{46}$ Por. H. H. Rex, Das ethische Problem in der eschatologischen Existenz bei Paulus, Tübingen 1954; J. Stępień, Oczekiwanie paruzji w Listach św. Pawta, Ruch Biblijny i Liturgiczny 14 (1961), s. 120-125.

${ }^{47}$ Zob. K. Romaniuk, dz. cyt., s. 245-246.

${ }^{48}$ Por. 1 Kor 7, 32-35.

${ }^{49}$ Por. A. Jankowski, K. Romaniuk, L. Stachowiak, dz. cyt., s. 732; E. Dąbrowski, dz. cyt., s. 203. 
„Troska o sprawy Pana"50 jest zadaniem wszystkich, bez względu na to, czy żyje się w małżeństwie, czy w celibacie. Jednak celibatariusze mają niejako bezpośredni dostęp do Pana, natomiast żonaci muszą iść do tego samego celu drogą okrężną, poprzez sprawy tego świata. Celibat zatem daje więcej możliwości do troskliwego dbania o sprawy Boże. Jest to jedyna forma okazania Bogu swojej pełnej i niepodzielnej miłości ${ }^{51}$.

„Troska o sprawy Pana"52 to również troska o uświęcanie samego siebie. Królestwo Boże powinno rozwijać się w sercach i duszach wiernych. Troska o rozwój tego Królestwa w bliźnich jest wystarczającym motywem dziewictwa. Bezżenność duchownych pozwala poświęcić się całkowicie, oddać swoje siły i czas Bogu i Jego sprawom; jest dzięki temu godziwa, szlachetna i godna naśladowania. Dlatego kapłan, służąc bliźnim - służy Bogu, przez różne formy duszpasterstwa dba o to, „co Pańskie" ${ }^{53}$.

Przez stawianie celibatu nad małżeństwem św. Paweł daje nam wskazówkę, jak najpełniej możemy „trwać przy Panu”. Apostoł domyślał się, że jego nauka może być niewłaściwie zrozumiana, dlatego wyjaśnia: "Mówię to dla waszego pożytku, nie zaś, by zastawiać na was pułapkę; po to, byście godnie i z upodobaniem trwali przy Panu"54. Słowa te wskazują na ostateczny cel naszych dążeń w każdej formie życia - czy to w małżeństwie, czy w bezżeństwie. Celem tym jest zjednoczenie z Bogiem, które skutecznie można zrealizować - jak wynika ze słów św. Pawła - żyjąc w celibacie $^{55}$.

Etyka prezentowana przez św. Pawła jest etyką całkowitego oddania się Bogu, kiedy człowiek dobrowolnie rezygnuje z osobistej wolności na rzecz oddania się do dyspozycji Boga ${ }^{56}$.

Podsumowując refleksję nad słowami Apostoła Narodów, trzeba powiedzieć wyraźnie, że głoszona przez niego doktryna jest bardzo zrównoważona, chociaż nie jest w pełni wyczerpująca i systematyczna. Musimy jednak mieć na uwadze fakt, że św. Paweł odpowiadał na konkretne pytania postawione przez gminę koryncka, w jej konkretnej sytuacji historycznej. Przeciw skrajnemu ascetyzmowi podkreśla on wartość małżeństwa. Z drugiej strony, ukazuje pra-

501 Kor $7,32$.

${ }^{51}$ Por. Z. Ziółkowski, Najtrudniejsze stronice Biblii, Warszawa 1989, s. 309; K. Romaniuk, dz. cyt., s. 110-111.

521 Kor 7, 32.

${ }^{53}$ Por. M. Wolniewicz, dz. cyt., s. 33; B. Cis, Społeczna rola celibatu, Ateneum Kapłańskie t. $61 / 52$, z. 3, nr 311 (1960), s. 320.

541 Kor 7, 35.

${ }^{55}$ Por. A. Jankowski, K. Romaniuk, Kaptaństwo w Piśmie Świętym Nowego Testamentu, Katowice 1972, s. 235; E. Szymanek, dz. cyt., s. 307; Epifaniusz z Salaminy, Panarion, w: PG 41, 868, 1024; tenże, Expositio Fidei, w: PG 42, 822-826.

${ }^{56}$ Por. K. Romaniuk, dz. cyt., s. 242; Euzebiusz z Cezarei, Demonstratio Evangelica, 1,9, w: PG 22, 78-83. 
womocność celibatu, opierając go nie zawsze na nakazie Bożym, ale na swoim autorytecie, jako Apostoła ${ }^{57}$. W wizji Pawłowej małżeństwo nie wyrasta ponad celibat, chociaż jest nieraz preferowane przed nim ${ }^{58}$, a celibat nieraz przewyższa małżeństwo i je relatywizuje. Na słowa: „Nie jest dobrze, żeby mężczyzna był sam"59, Paweł odpowiada: „Uważam, iż przy obecnych utrapieniach dobrze jest tak zostać, dobrze to dla człowieka tak żyć"60.

Niezależnie od logionu Jezusa, zawartego w Ewangelii św. Mateusza ${ }^{61}$, wskazania pastoralne przekazane przez Apostoła Koryntianom dają prawo do nadania celibatowi podstawy chrześcijańskiej. Rady udzielone odnośnie do celibatu, jako uprzywilejowanego statusu, nie zawierają w sobie charakteru ani ascetycznego, ani moralizującego. Eschatologiczna wizja Pawła pozwala na odkrycie ważnej funkcji celibatu i podstaw relatywizowania przez niego małżeństwa: celibatariusz pozostaje mniej wrażliwy na sprawy ziemskie i może „poświęcić się sprawom, które podobają się Panu”62.

Nauczanie św. Pawła w 1 Kor 7 wskazuje, że celibat powinien być rozważany również w kontekście eschatologicznym. Jakkolwiek uważa on małżeństwo za rzeczywistość dobrą ${ }^{63}$, to jednak przekonuje, że lepiej pozostać bezżennym ${ }^{64}$ z dwóch racji: problemy ziemskie ${ }^{65}$ i udręki w ciele ${ }^{66}$. Racją pozytywną jest możliwość większej troski o „sprawy Pana”67.

W tej sytuacji zauważa się, że dla Pawła celibat stanowi stan odpowiadający sytuacji chrześcijanina; jest środkiem większej doskonałości etycznej ${ }^{68}$, przy czym Apostoł nie wyjaśnia głębiej jego natury teologicznej.

W kontekście teologii kapłaństwa i jego eschatologicznej perspektywy, pisze D. Wuerl, zostało umieszczone zagadnienie celibatu kapłańskiego jako znaku Królestwa Bożego i charyzmatu przypisywanego kapłanowi. Rzeczywistość życia ludzkiego i kapłańskiego określił Jezus Chrystus w refleksji dotyczącej przyjścia pełni Królestwa. Ujął ten temat w ramach życia i egzystencji, przez którą człowiek jest w stanie zrozumieć życie przyszłe i nastanie Królestwa. Jeśli utraci się wizję obecnego dnia Kościoła jako początku Królestwa i potrzeby zrozumienia

${ }^{57}$ Por. 1 Kor 7, 25.

${ }^{58}$ Por. 1 Kor 7, 9.

${ }^{59} \mathrm{Rdz} 2,18$.

${ }^{60} 1$ Kor 7, 26.

${ }^{61}$ Mt 19, 12.

${ }^{62} 1$ Kor 7, 32.

${ }^{63}$ Zob. 1 Kor 7, 7. 8. 26.

${ }^{64}$ Por. 1 Kor 7, 38-40.

${ }^{65}$ Por. 1 Kor 7, 26.

${ }^{66}$ Por. 1 Kor 7, 28.

${ }^{67} 1$ Kor $7,32$.

${ }^{68}$ Por. T. Matura, Le célibat dans le Nouveau Testament d'aprés l'exégése recente, Nouvelle Revue Théologique 7/1975, s. 597. 
początku w perspektywie wypełnienia, to tym samym znika rozumienie samego Kościoła. D. Wurel przedstawia ten pogląd, powołując się na tekst św. Pawła, który pisze o małżeństwie jako znaku nieskończonej jedności Chrystusa z Kościołem ${ }^{69}$. W tym sensie małżeństwo jest eschatologicznym znakiem. Nie należy go rozumieć w kategoriach miłości jednoczącej dwoje ludzi, lecz akcentować pełnię miłości w Królestwie, które będzie nieskończoną wspólnotą wzajemnej miłości, przekraczającej całkowicie ograniczenia znaku, czyli fizycznej jedności w ludzkim małżeństwie ${ }^{70}$.

Studium Pawłowych tekstów o małżeństwie i bezżeństwie ukazuje dwa tory myślowe Apostoła. $Z$ jednej strony uważa on celibat za charyzmat Boży, z którym związane są pewne korzyści, z drugiej zaś wynosi małżeństwo do bardzo wysokiej rangi. Skąd tego typu dualizm? Nie można go tłumaczyć ani podwójną moralnością, ani dwoma stopniami doskonałości. Korzyści z celibatu mają dla Apostoła charakter praktyczny. Nie oznacza to jednak, że celibat jest zarezerwowany tylko dla apostołów, a małżeństwo dla wiernych.

Nauka Apostoła stara się odpowiedzieć na pytanie: jak pierwotne chrześcijaństwo, na podstawie Ewangelii i znajomości natury człowieka, ustosunkowało się do obyczajowego rozluźnienia Greków i Rzymian, a zarazem ukazać, że starało się ono także dać odpowiedź rygorystom z różnych sekt gnostyckich ${ }^{71}$.

\section{IL VALORE DEL CELIBATO NEGLI INSEGNAMENTI DI S. PAOLO}

\section{RIASSUNTO}

San Paolo nella prima lettera ai Corinzi (1 Kor 7) ha presentato il valore soprannaturale del celibato. Già nel primo versetto troviamo l'espressione che è meglio vivere nel celibato piuttosto che legarsi ad una donna. L'apostolo non suggerisce che ogni legame tra uomo e donna è sbagliato. Non vuole fare il paragone tra "bene"e "male",ma tra "bene" e "meglio". S. Paolo non sminuisce il valore del matrimonio, ma conoscendo bene la natura umana, non a tutti consiglia di scegliere questa forma della vita, qual' è il celibato. Il celibato non è un dovere ma ha un senso, solo se viene scelto liberamente, come dono. Spetta all' uomo riconoscere e capire questo dono e anche dare una risposta alla chiamata di Dio. Negli occhi dell'apostolo dei pagani, il celibato è un carisma e non una semplice vocazione. Il carisma è legato alla comunione e lo Spirito Santo benedice colui che vivrà il celibato. E' per questo che la Chiesa unisce il servizio sacerdotale con il celibato, perché è convinta che questa forma di vita per un candidato al sacerdozio carismatico è stato confermato dallo Spirito Santo. Il dono non è stato abolito con delle leggi, ma le leggi hanno formato le condizioni interne, che permettono la totale consegna alla causa del Regno di Dio.

${ }^{69}$ Por. D. Wuerl, The relationship of celibacy to priesthood, The Priest 11 (1987), s. 31; por. Ef 5, 25-32.

${ }^{70}$ Por. D. Wuerl, dz. cyt., s. 31.

${ }^{71}$ Por. E. Dąbrowski, Św. Pawet, Poznań 1952, s. 168. 
Se S. Paolo preferisce il celibato, non è per motivi teologici, ma per motivi pratici e sottolinea che la sua affermazione non ha carattere come ordine impartito da Gesù, ma è solamente un consiglio umano. Le motivazioni dall'apostolo a proposito del celibato, sono le fatiche sulla terra, specialmente le sofferenze legate alla futura venuta di Gesù sulla terra. Il celibato è il modo più adatto per aspettare la venuta di Gesù. Il celibato è un segno escatologico e possiede dei valori che non passano mai, perché la vita iniziata sulla terra in questo modo continuerà nell' eternità. Il matrimonio invece è un elemento della vita che passa e finisce quando avremo una nuova realtà dei risorti. S. Paolo segnala anche l'argomentazione psicologico-morale nella vita del celibe: il celibato è meglio del matrimonio perchè permette all' uomo di dedicarsi completamente a Dio. L'uomo celibe può dedicare completamente al Signore tutto il suo cuore,senza necessità di dividerlo tra Dio e la famiglia. 